\title{
Groundnut Seed Production and Distribution Through Multi- Stakeholder Platforms in Southern Region of Tanzania
}

\author{
Gerald Alex Lukurugu, Omari Kalanje Mponda, \\ Essegbemon Akpo, Emmanuel S. Monyo, Joseph Nzunda, \\ Happy Daudi, Athanas Joseph, \\ Hamphfrey George Mlimbila, David Ndolelwa, \\ and Charles Mkandawile
}

\begin{abstract}
Southern Groundnut Platform (SGP) was established in 2016 to enhance seed access and adoption of improved groundnut varieties by farmers. The platform serves all districts in Lindi and Mtwara regions and Tunduru district in Ruvuma region. The platform has 53 members of which 22 are females and 31 are males. Since its establishment, there has been a marked increase in farm advisory services using government extension officers, community extension services and lead farmers. Groundnut seed production and distribution networks have increased to include more actors such as NGOs, seed companies, farmers groups and individual seed entrepreneurs. The increased seed access to farmers in the southern zone has contributed to $11 \%$ increase in area under cultivation resulting in $15 \%$ increase in groundnut production in Nanyumbu district between
\end{abstract}

G. A. Lukurugu $(\bowtie) \cdot$ O. K. Mponda $\cdot$ J. Nzunda $\cdot$ H. Daudi $\cdot$ A. Joseph $\cdot$ H. G. Mlimbila

D. Ndolelwa $\cdot$ C. Mkandawile

Tanzania Agricultural Research Institute (TARI), Dodoma, Tanzania

E. Akpo

International Crops Research Institute for the Semi-Arid Tropics (ICRISAT), Nairobi, Kenya

E. S. Monyo

Alssem Company Limited, Arusha, Tanzania

(C) The Author(s) 2021

E. Akpo et al. (eds.), Enhancing Smallholder Farmers' Access to Seed of

Improved Legume Varieties Through Multi-Stakeholder Platforms,

https://doi.org/10.1007/978-981-15-8014-7_2 
2012 and 2018. New market linkages formed helped improve farm gate prices by $80 \%$ (from Tshs. 1000 to 1800). The platform also introduced 29 new labour saving technologies reducing women drudgery and increasing farmer improved varieties choice from 3 to 11 new varieties released between 2009 and 2018 .

\section{Keywords}

Improved groundnut varieties · Quality declared Seed · Smallholder farmers · Innovation platform

\section{$2.1 \quad$ Introduction}

Tanzanian seed sector has a wide variety of public, private sector and civil society actors. The breeding programme in the country is conducted by both public and private sectors. Public sector breeding programme is conducted through a network of seven zonal centres of Tanzania Agricultural Research Institutes (TARI) located throughout the country (ASARECA/KIT 2014). A number of private seed companies including SeedCo, Suba Agro, Kibo Seed Co. ltd, Pioneer and Monsanto have also invested in seed breeding, predominantly in maize (Kalinda et al. 2014). The breeding materials used by the public sector are primarily sourced from the international agricultural research institutions such as International Maize and Wheat Improvement Center (CIMMYT) e.g. maize, the World Vegetable Center (AVRDC) e.g. tomato and leaf legumes, or International Crops Research Institute for the Semi-Arid Tropics (ICRISAT) e.g. groundnut (Madulu et al. 2016). However, other breeding materials are also sourced within the public sector e.g. National Agricultural Systems (NARS).

In Tanzania, the groundnut breeding programme aims to develop and maintain improved varieties after it is released. At the production stage there are four classes of seeds produced including breeder or pre-basic seed, foundation or basic seed, certified seed and quality declared seed (QDS). Each category of seed is public registered class. Breeder seed of public varieties is produced by the TARI's centres (chiefly by TARI Naliendele, Mtwara), while basic, or foundation, seed is produced almost exclusively by the public seed company Agricultural Seed Agency (ASA). The production, processing and storage of certified seeds are done by private seed companies. The quality declared seed is produced and marketed by farmer groups, private seed entrepreneurs with the confinement of the ward geographical area. According to the seed unit of Ministry of Agriculture (MoA), there are 65 registered seed companies in Tanzania producing certified seeds.

Seed is primarily sold through agro-dealers, although some seed companies and the ASA also engage in direct sales to farmers. The MoA has a list of over 4000 registered agro-dealers; however, only half of them are estimated to be actively selling inputs (Chambers et al. 2013). The enabling environments that impact the entire seed value chain include government institutions (MoA, Tanzania official Seed 
certification Institute (TOSCI)) responsible for the variety release and registration, plant variety protection, seed certification, seed related enterprise registration and quality control in the seed market. Another component in the commodity value chain is seed market demand. This involves the end users of grain products.

In Tanzania, an estimated $75 \%$ of farmers continue to source their seeds through the informal seed system (Chambers et al. 2013). Access of seed through the formal systems is undermined by high seed prices, insufficient awareness of the benefits of certified seed, poor quality control of the formal seed market and a lack of output markets to absorb the increased production from improved seed technologies (ASARECA/KIT 2014). Most of the 65 registered seed companies in Tanzania are located in Arusha. The concentration of seed production in the North adds significant transportation costs to the price of seed in the market. Out of 65 registered companies, only seven seed companies have expressed interest of producing groundnut seeds (ASA, Temnar, Suba agro, Meru Agro, Alssem, Mbozi Highland Economic Group and Iffa seed co.). Most of these companies have started bulking groundnut seeds very recently say 2016-2017 after the intervention of TLIII project hoping that they will grow and become substantial contributors in production of groundnut seed through the Innovation Platforms like SGP. Therefore, groundnut certified seeds were hardly to be found before TLIII project. Only Quality Declared Seeds (QDS) were accessed by farmers through Farmer Research Groups, NonGovernmental Organizations and Individual seed entrepreneurs in the country. To increase groundnut seed access in the country, various multi-stakeholder platforms were established at national, zonal and district levels through TLIII project. The main objective of these platforms was to facilitate interactions, learning and innovation among different actors along the groundnut value chain to increase the productivity and production for different communities through improved and recently released varieties, and build capacity of smallholder groundnut farmers in the country. This paper highlights the key processes that made the multi-stakeholder platform, the key achievements and lessons learned in bringing improved legume seed to scale in Tanzania. In the next sections, we present the platform establishment, its composition, roles and responsibilities, and main activities.

\subsection{Establishment of the Platform}

In 2016 the Groundnut platform in the south eastern of Tanzania was established and called "Southern Groundnut Platform". The main aim of this platform was to enhance seed access and adoption of improved groundnut varieties in the southern zone of the country. The zone serves Lindi and Mtwara regions and Tunduru district in Ruvuma region. Southern Groundnut Platform had 43 members when it was established in 2016. It has since grown to 53 members in 2018 of which 22 are females and 31 are males. It is worth noting that only six members out of 53 are youth (less than 35 years).

The establishment of Southern Groundnut Platform involved two meeting procedures. The first step was diagnostic. This step involved a team of two researchers 
from TARI Naliendele, two groundnut traders and three District Agriculture Irrigation \& Cooperative Officers (DAICO's) and one seed company representative. The team identified major challenges as well as opportunities in the groundnut values chain and relevant actors who could effectively resolve the identified challenges and/or opportunities. The major challenges identified included low adoption of improved groundnut varieties and marketing problems in the southern zone. The second meeting was conducted with all stakeholders to validate the identified challenges, to share information among actors and discuss how best to address the key challenges. Moreover, at this step the Southern Groundnut Platform was formally launched and all actors committed to address low adoption of improved groundnut varieties and marketing linkages to smallholder farmers. The major output was development of workplans to address the challenges and putting in place rules and regulations governing the operationalization of the Southern Groundnut Platform.

\subsection{Composition, Roles and Responsibilities of the Platform Members}

The Southern Groundnut Platform is composed of different actors having different roles and responsibilities as shown in the Table 2.1.

The platform has 53 members of different categories including Groundnut Researchers (5), extension unit (4), seed companies (3), Media people (6), Farmer Research Groups (6), Policy makers (2), Individual seed entrepreneurs (3), Grain Traders and Processors (5), financial institutions (2), Agro-dealers (1), NGOs (2), Local Government Authorities (4), Regulatory Authorities (6), Transporters (3) and Agricultural Marketing Cooperatives (AMCOS) (1).

\subsubsection{Platform Governance Structure, Steering Committee and Arrangements in Place to Facilitate Smooth Implementation of Platform Activities}

To ensure Southern Groundnut Platform better delivers outcomes to the members, a steering committee was formed to facilitate platform decision-making and implementation process. The steering committee composed of researchers, extension, NGOs and skilled representatives of primary beneficiaries. For the platform to solve emerging specific issues, working groups were formed involving different actors based on their interest in the groundnut value chain. Three working groups were formed: (1) Seed producers' group (Researchers, FRGs, Individual farmers and seed companies); (2) Seed marketing group involving seed companies, NGOs, Processors, LGAs and certification and (3) financing group (Banks, SACCOSS, VICOBA). For the platform activities to run smoothly every actor uses her own resources to gain her interest. 


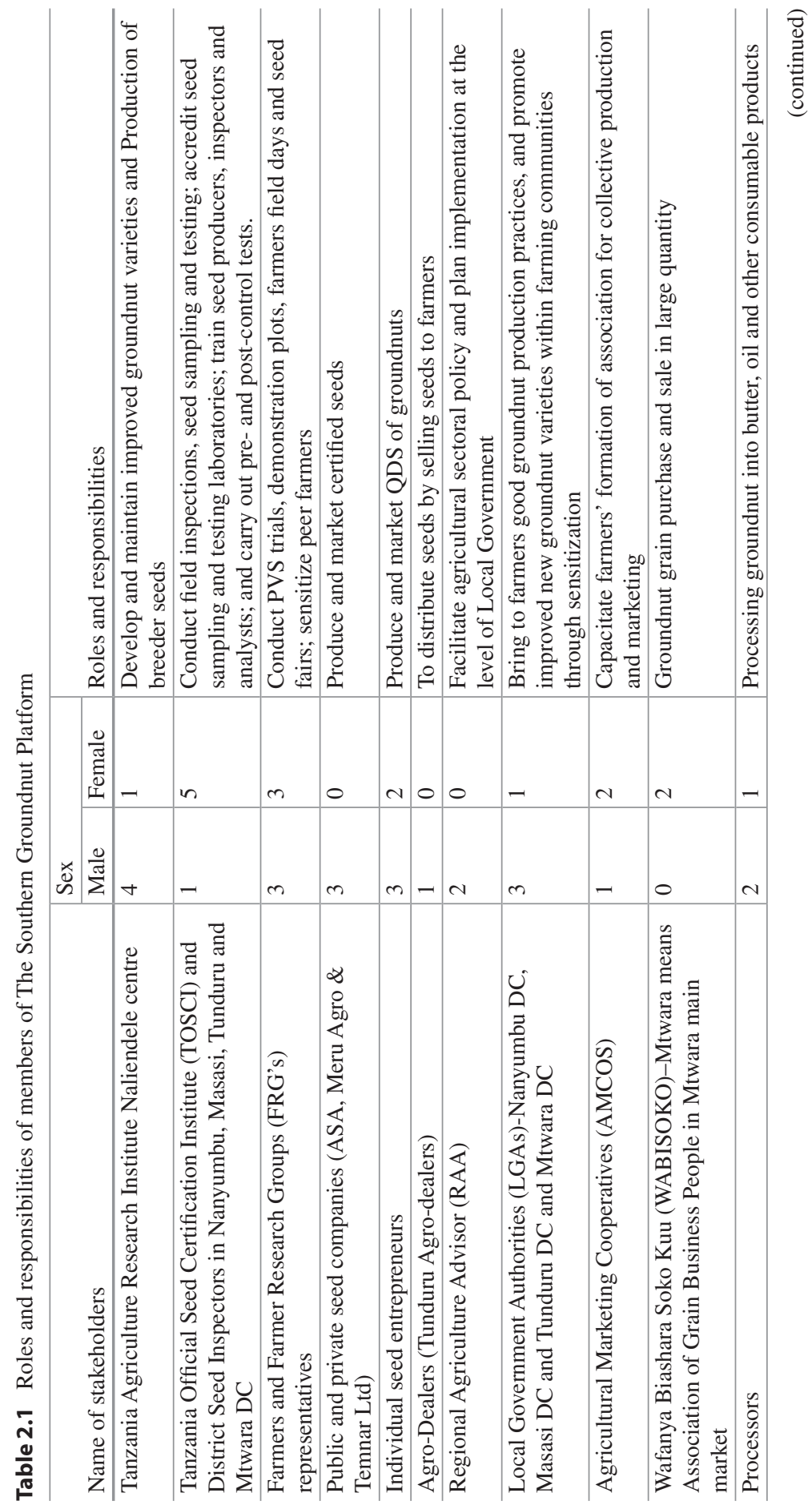




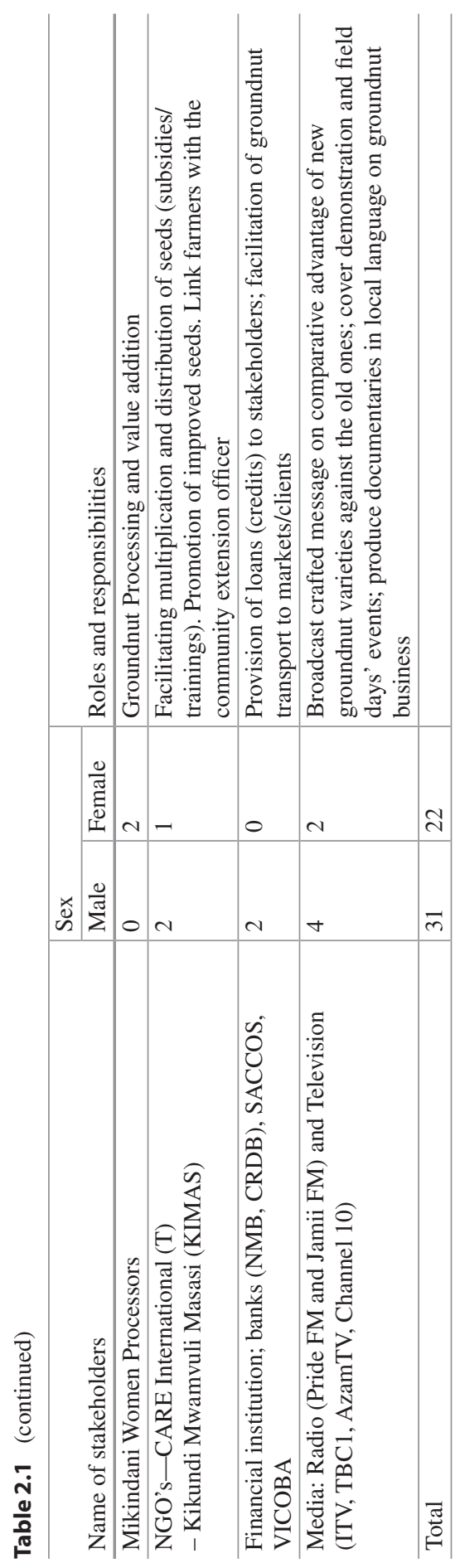




\subsection{Platform Activities}

\subsubsection{Description of the Different Platform Activities}

Southern Groundnut Platform (SGP) was set up to create awareness of groundnut improved varieties to farmers and other stakeholders, scale out adoption of groundnut seed, increase pre-basic, basic, certified and QDS seed production. Furthermore, the other key function is to increase groundnut Market linkages and networking.

\subsection{Creating Awareness Through Popularization of Improved Groundnut Varieties}

To achieve the above objective, platform members established demonstration plots, organized field days and seed fairs, conducted trainings to farmers, seed companies and individual seed entrepreneurs on improved seed production and marketing.

\subsubsection{Establishment of Demonstration Plots}

In the southern zone more than 100 demonstrations were established in Masasi, Nanyumbu, Tunduru and Mtwara districts to showcase improved released varieties. In these demonstrations the released and local varieties are compared side by side on a 0.25 acre plots for farmers to practically self-appreciate their performance and preferred traits. Traits observed included yield, pest and disease resistance, drought tolerance, maturity, pod filling and number of pods per plants. Varieties demonstrated included Mnanje 2009, Naliendele 2009, Mangaka 2009, Masasi 2009, Nachingwea 2009 and Nachi 2015. Furthermore, since 2015-2018, a total of 2942 farmers participated in these demonstrations of which 1339 are females and 1603 are males.

\subsubsection{Farmer Field Days}

Platform members organized farmer field days on the demonstration plots to showcase Good Agricultural Practices (GAP) and performance of improved groundnut varieties with implementing farmer groups or individual seed entrepreneurs. The events gave platform members a chance to showcase their achievements by using improved groundnut varieties and the general farming population an opportunity to know about the varieties. Members showed good practices for sustainable groundnut production to fellow farmers and other stakeholders. The field days were typically hosted by farmers themselves with some assistance from Extension officers, NGOs Staffs and TARI Naliendele researchers. The host farmers share information and farming practices with participants and engage in discussion to learn from each other. Participants in these field days included researchers from TARI Naliendele, 
policy makers at ward level (ward councillors), seed companies, extension officers at district and village levels, farmers within and nearby villages, Religious Institutions, Media workers (radio and TV programmes), Agricultural students in primary and secondary schools and NGOs. The Southern Groundnut Platform organized a total of 24 field days in Mtwara, Masasi, Nanyumbu and Tunduru districts during 2015-2018. In these field days a total of 12,408 farmers participated of which 5782 are females and 6626 are males. Moreover, 4621 promotional materials including leaflets, factsheets and production guides were distributed to participants during field days. The number of female and male participants who received promotional materials distributed during field days was 2956 and 1665, respectively.

\subsubsection{Agricultural Seed Fairs and Exhibition Shows}

This was another method used by SGP members to popularize the improved groundnut varieties. Most of these events were done in the rural areas in the village settings where seed companies, Farmers groups, Agro-dealers, Researchers, media partners, Extension officers and farmers were invited as part of increasing farmers' awareness and access to improved groundnut varieties (Fig. 2.1). Not only groundnut varieties were promoted but also improved seeds of other crops were displayed. This gave a chance to agro-dealers, seed companies, farmer groups and other stakeholders to promote their work and sell their product to farmers.

The Southern Groundnut Platform (SGP) successfully organized and participated in four National Agricultural Exhibition shows and three rural seed fairs from 2015 to 2018. The national agricultural exhibition shows were conducted in Ngongo Lindi while the rural seed fairs were conducted in Nanyumbu, Masasi and Tunduru

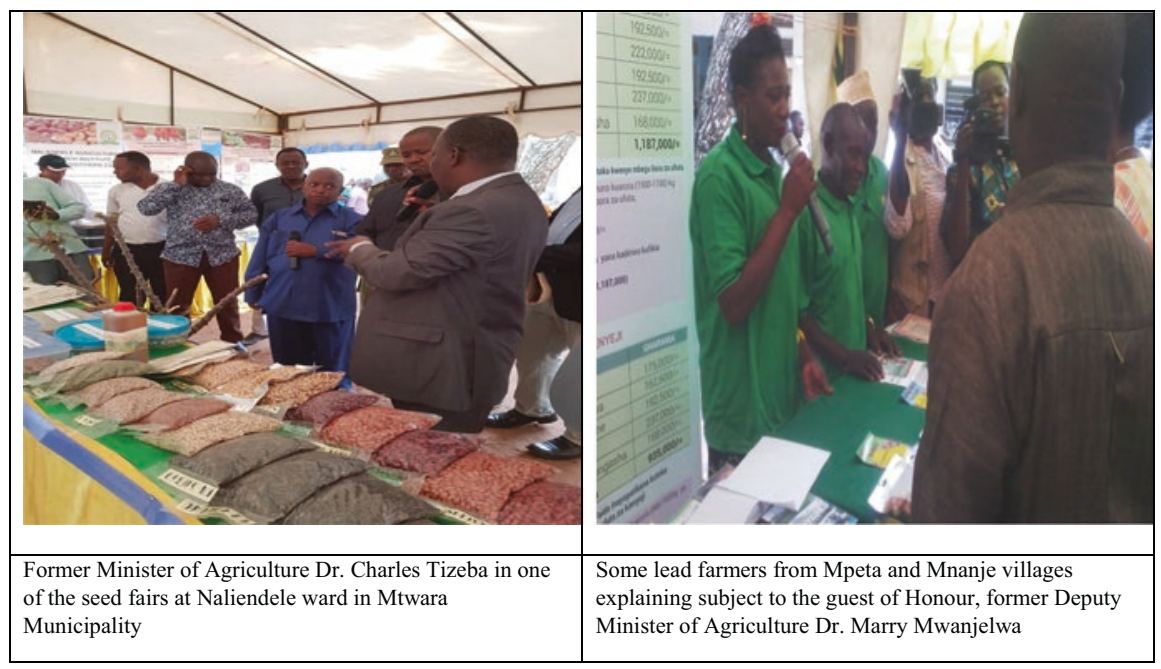

Fig. 2.1 Participants at seed fairs in Mtwara 
districts at Mnanje, Mpeta and Ligunga villages, respectively. Moreover, 7280 farmers and other stakeholders (3159 females, 4121 males) visited different technologies displayed.

\subsubsection{Disseminating Electronic (TV and Radio) Programmes and Print Media}

For the groundnut technologies to reach a wider audience, different TV and radio programmes were recorded and aired through different TV and radio stations. The locally available radio stations in the southern zone were used including Pride FM, Safari FM and Info radio. Moreover, Tanzania Broadcasting Corporation (TBC1), Channel 10, AzamTV and ITV Tanzania were among the TV stations used to popularize groundnut improved varieties. These media were used to promote different improved groundnut varieties to the farmers. Six groundnut varieties including Mangaka 2009, Mnanje 2009, Nachingwea 2009, Naliendele 2009, Masasi 2009 and Nachi 2015 were promoted widely through the above-mentioned stations. These have increased the demand of improved groundnut varieties not only to the southern zone but also to the whole country. People from different parts of the country are now demanding improved groundnut varieties. Since 2015 to 2018, the platform facilitated $69 \mathrm{TV}$ and Radio programmes and printed information that have been recorded and broadcasted by TBC1, ITV Tanzania, Channel 10, AzamTV, Habari Leo, and Mwananchi newspapers.

\subsubsection{Conducted Farmer Participatory Variety Selection (FPVS)}

Farmer Participatory varietal selection (FPVS) involved farmers in selecting finished or near finished groundnut elite germplasm from plant breeding programmes to ensure that farmer input is included in the breeder decision-making process before releasing the varieties. The process exposed farmers to different groundnut planting materials that will be available to them even after the release of improved groundnut varieties. From 2015 to 2018, a total of 3506 farmers participated in FPVS of which 1440 are males and 2066 are females. The FPVS increased farmer access to improved planting materials and help them select groundnut cultivars that better suit their local growing conditions and market demand. Seven (7) groundnut cultivars including five pre-released varieties and two released groundnut cultivars were used in FPVS. The pre-released groundnut varieties used were ICGV-SM 08503, ICGV-SM 07599, ICGV-SM 01514, LOCAL and ICGV-SM 07509. While the released groundnut varieties used in FPVS were Mangaka 2009 and Nachi 2015. 


\subsection{Increase Production of Pre-Basic, Basic, Certified/QDS Seeds of Groundnut Varieties}

Members of the SGP observed that, there was low production and access of improved groundnut varieties in their zone and proposed joint collaboration for increased production of pre-basic, basic, certified and QDS seed. Responsibility of producing pre-basic seeds was given to researchers while production of basic seeds was under the responsibility of Agricultural Seed Agency (ASA) which is a public seed company. Certified seeds in the southern zone were under a private seed company called TEMNAR co. Ltd. Responsibility of QDS production was given to Farmer Research Groups, NGOs through their farmers' network, Primary and secondary schools and Religious institutions (Churches and Mosques) and individual seed entrepreneurs within communities.

\subsubsection{Pre-Basic Seed Production}

To ensure enough seed is available to different stakeholders, TARI Naliendele improved its irrigation infrastructures under TLII project support by increasing production cycles within a season (Fig. 2.2). This has enabled TARI to produce more than $40.8 \mathrm{t}$ of pre-basic seeds for the period from 2015 to 2018.

\subsubsection{Basic Seed Production}

Thanks to the platform initiative, the Agricultural Seed Agency has started producing groundnut basic seed of Mnanje 2009, Naliendele 2009 and Mangaka 2009 since 2016. From one seed production site in 2016, ASA has now increased to three to get basic seed much closer to groundnut farming communities. In 2018/2019 farming season ASA has cultivated 8 ha of groundnuts including 4 ha for Mnanje 20092 ha for Naliendele 2009 and Mangaka 2009 respectively. To complement ASA effort in basic seed production, TARI Naliendele used to sub-contract ten Farmer Research Groups and five individual seed entrepreneurs to produce groundnut basic seeds in the southern zone. The basic seed produced was sold back to TARI Naliendele. The basic seeds bought were distributed in the form of seed loan to other farmer groups, NGOs, Individual seed entrepreneurs to produce QDS seeds that are sold to other farmers in the zone. For decentralized basic seed production, TARI Naliendele has established linkages with other sister research stations i.e. TARI-Tumbi in Western zone, TARI-Uyole in the Southern Highlands, TARIUkiriguru in the Lake Zone and TARI-Makutupora in the central zone. The collaborative efforts with other sister research stations managed to produce 12 tons of basic seed from 2015 to 2018. 


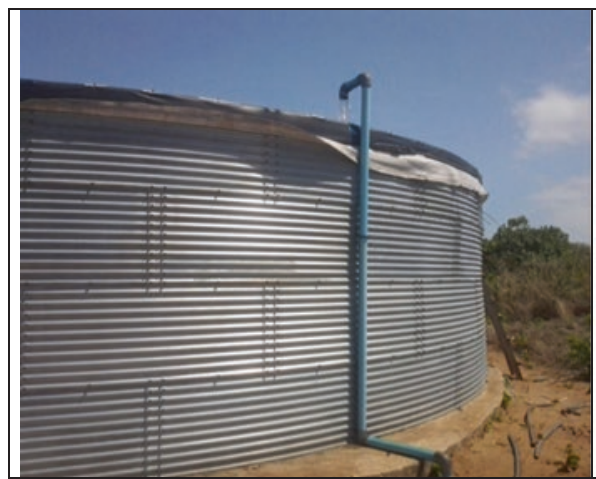

Water tank with a capacity of 500,000 Litre to facilitate pre-basic seed production at TARI Naliendele

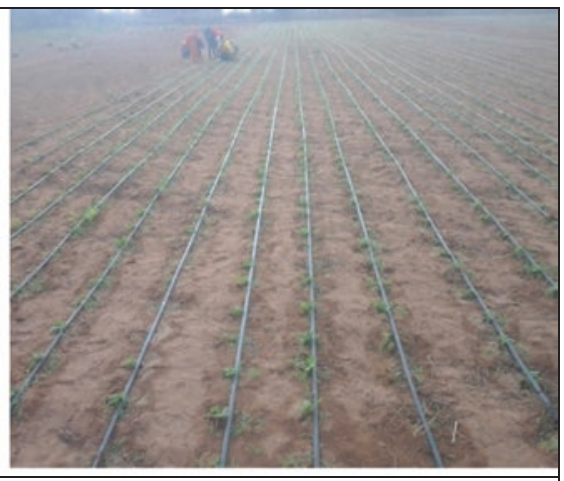

3 acres of Drip Irrigation for pre- basic seed production at TARI Naliendele

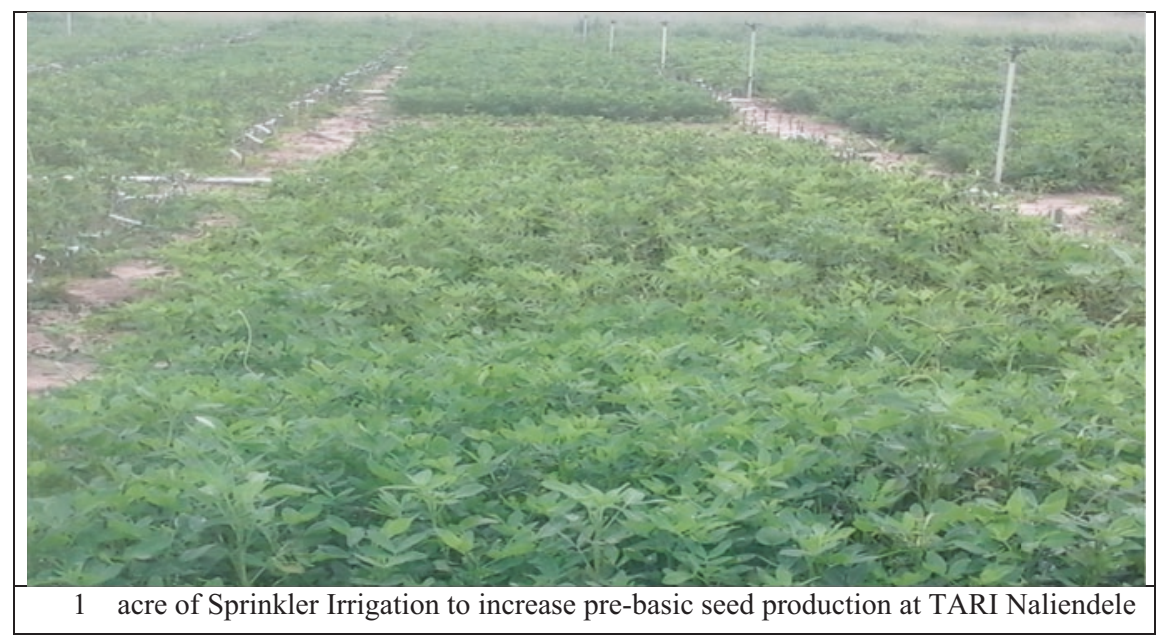

Fig. 2.2 Irrigation facilities for increasing breeding cycle and pre-basic seed production

\subsubsection{Certified Seed Production}

The platform through TLIII project has elicited both public (ASA) and private seed companies (TEMNAR, MERU AGRO, IFFA and SUBA AGRO) who have already started bulking certified seeds. In the southern zone, Temnar company Ltd. and Meru Agro and Tour Consult Ltd. are also producing groundnut certified seeds. IFFA seed company and Suba Agro are producing groundnut in Mbeya regions as well. 


\subsubsection{QDS Production}

To increase improved seed access to farmers in remote communities, the platform in the southern zone has facilitated linkages with five NGOs including CARE international through WWF, AGAKHAN foundation, Anglican Church Diocese of Masasi, SWISS Aids and Nawaje Mosque in groundnut seed production through their Farmers' Networks. Moreover, the platform has established a base of 137 farmer research groups in Mtwara, Lindi and Tunduru district in Ruvuma region to produce QDS seeds. Furthermore, the programme is working with 107 individual seed entrepreneurs (63F, $44 \mathrm{M}$ ) in QDS production. From 2015 to 2018, the platform through its collaborative efforts with other partners produced 446 tons of QDS seeds in the southern zone.

\subsection{Market Linkages and Networking}

During the platform meetings distinguishing traits of the improved groundnut varieties were identified as a selling strategy of these varieties to consumers. These were compiled into leaflets, factsheets and other promotional materials and aired into different TV and radio programmes to create demand of improved groundnut varieties. Some of the distinguished traits of the promoted groundnut varieties are presented in Table 2.2.

Farmers in the southern zone were linked to RECODA, LGA and different traders who buy groundnut seed and sell to other stakeholders throughout the country.

The above-mentioned platform activities managed to address three main challenges including inadequate supply and access of improved groundnut seeds, poor

Table 2.2 Market-driven traits

\begin{tabular}{|c|c|c|}
\hline Variety name & $\begin{array}{l}\text { Year of } \\
\text { release }\end{array}$ & Market-driven traits \\
\hline Mnanje 2009 & 2009 & $\begin{array}{l}\text { - Highest oil content }(51 \%) \text { than other released varieties } \\
\text { - Has highest Iron } 65.4 \mathrm{mg} / \mathrm{kg} \\
\text { - Very sweat when cooked and in raw form }\end{array}$ \\
\hline Mangaka 2009 & 2009 & $\begin{array}{l}\text { - Highest zinc } 94.5 \mathrm{mg} / \mathrm{kg} \text { than other released varieties } \\
\text { - Has 2-3 kernels per pod }\end{array}$ \\
\hline $\begin{array}{l}\text { Naliendele } \\
2009\end{array}$ & 2009 & $\begin{array}{l}\text { - Highest protein }(34.5 \% \mathrm{w} / \mathrm{w}) \text { than other released varieties } \\
\text { - Maturity } 90-100 \text { days }\end{array}$ \\
\hline Masasi 2009 & 2009 & $\begin{array}{l}\text { - High oil content ( } 46.9 \% \text {, second to Mnanje) and resistant } \\
\text { to rosette }\end{array}$ \\
\hline $\begin{array}{l}\text { Nachingwea } \\
2009\end{array}$ & 2009 & $\begin{array}{l}\text { - Maturity } 110-120 \text { days } \\
\text { - Contain } 77 \mathrm{mg} / \mathrm{kg} \text { zinc }\end{array}$ \\
\hline Nachi 2015 & 2015 & $\begin{array}{l}\text { - Yield potential } 2 \mathrm{t} / \mathrm{ha} \\
\text { - Has high protein }(32.4 \mathrm{mg} / \mathrm{kg}) \text { third to Naliendele } \\
\text { - Bold seeds and resistant to rosette disease }\end{array}$ \\
\hline
\end{tabular}


awareness and adoption of improved groundnut varieties and poor marketing linkages and poor networking.

\subsubsection{Facilitation of Platform Activities, Including Meetings}

The first meeting of Southern Groundnut Platform was organized by TARI Naliendele, where all cost related to the meeting were supported by TARI through TLIII project. However, other subsequent meetings were supported by members' organization and/or institute and TARI Naliendele only supported venue and meal (breakfast and lunch) for all participants. To enhance stakeholder participations, mainly farmer groups which by one reason or another had challenges in their specific seasons i.e. drought, pest and diseases, flood and affected groups income, TARI Naliendele had to support them attend annual meetings. All the meetings were called by TARI Naliendele. During the meetings participants vote for a chairman among the two proposed members, the timekeeper is also selected and a secretariat involving four members for capturing participants' inputs during the meeting is also selected among the meeting participants. During the meeting all members are given equal chance to contribute to the meeting agenda provided. Both oral and written contribution from meeting participants are noted by secretariats and presented at the end of the meeting. Then all participants pass through different issues presented by secretariat to reach agreements. The agreed issues will be shared as a meeting outcome to all members for implementation.

\subsection{Achievements of the Platform}

\subsubsection{Increased Contacts with Extension and Farm Advisory Services}

To ensure proper access to knowledge and farm advisory services to all stakeholders in groundnut value chain, the platform members used government extension services to reach farmers in the villages. Most of the villages and wards in southern zone have extension officers to serve farmers in their respective communities. In places where there is no government extension officer, the community extension service and lead farmers created by NGOs were used to reach their fellow farmers within the village. The approach of using community extension services is widely used by NGOs especially in places where there are limited government extension services.

Before membership to SGP majority of farmers in Mtwara, Masasi, Nanyumbu and Tunduru districts had limited knowledge of how to control pests and diseases, good agronomic practices (seed rate, spacing and good post-harvest management). After membership to SGP, farmers got more acquainted to extension officers within the districts who are fully mobilized to reach farmer groups. Community extension services, lead farmers, farmer group representatives and government extension 
officers who were trained on good groundnut production and post-harvest practices got much closer to farmers, many of whom had never had previous contact with advisory services. Farmers were also trained on business management skills. For example, farmers in Mpeta, Mnanje and Kidodoma villages in Masasi, Nanyumbu and Tunduru districts, respectively, were among the farmers who benefited from farming as business training intervention offered through TLIII. The other intervention was that conducted by Masasi High Quality Farmers Produce (MHQFP) Ltd., a farmer association responsible for increasing farmers' income. They trained 2103 farmers in 25 villages in Masasi district on good agricultural practices and importance of using improved varieties.

\subsubsection{Achievements in the Areas of Access to Improved Seed and Other Inputs}

Before membership to SGP groundnut farmers used old improved varieties released in the 1990s or before such as Pendo released in 1998, Johari released in 1985 and Nyota released in 1984. These old varieties were susceptible to rosette and other foliar diseases. Moreover, farmers also used their other local varieties such as Kanyomwa, Chimbuvila and Karanga njugu that are no longer adapted to current biotic and abiotic stresses and current market demand. It is worth noting that out of the old released varieties, Pendo 1998 was the most popular variety compared to others. Furthermore, before membership only farmers groups that had direct access to TARI Naliendele had access to improved seeds.

Membership to SGP brought much improvement in terms of seed access to farmers. SGP involved NGOs such as CARE international, Agakhan Foundation, Anglican Church Diocese of Masasi, Rural Oriented Sustainable Development Organization (ROSDO), Masasi High Quality and SWISSAID which have farmer networks in the regions. Improved seeds through these NGOs have widened the coverage areas and farmers throughout the zone. For example, through Masasi High Quality, 2103 farmers have accessed improved seed in 25 villages in Masasi district from 2014-2017. Moreover, ROSDO managed to distribute improved seed to 2700 farmers out of 5000 farmers in Mkapunda and Lisekese villages in Masasi district. In collaboration with NGOs farmers' network, a total of 1799.9 t of QDS seeds have been produced from 2016-2017 alone in the southern zone. Moreover, the number of improved varieties accessed by farmers increased from three old varieties to six new varieties. Farmers were able to replace the old varieties that were susceptible to foliar diseases to recently released improved groundnut varieties that are high yielding, drought tolerant and resistant to foliar diseases. The recent varieties stakeholders accessed after membership included Mnanje 2009, Naliendele 2009, Masasi 2009, Mangaka 2009, Nachingwea 2009 and Nachi 2015. Furthermore, not only platform members have benefited from the disseminated improved varieties. Through spill-over effects, other non-members have also gained from activities of the platform. For example, farmers in Mnanje village in Nanyumbu district who are members of SGP have shared improved seeds to more than $90 \%$ of groundnut farmers in their village. Beyond their communities, it was reported that they have sold improved seeds to other district councils e.g. Ruangwa, Lindi, Newala and 


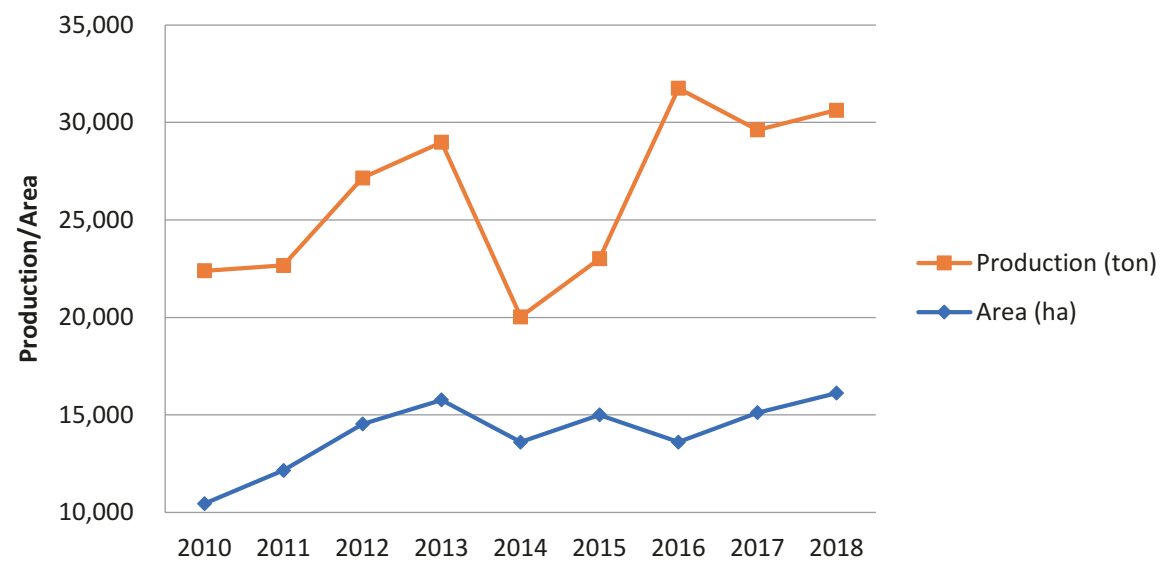

Fig. 2.3 Area and production of groundnut from Nanyumbu district from 2010 to 2018. Source: Nanyumbu District Council (2019)

Shinyanga. A total 11,250 farmers in 25 neighbouring villages have also benefited from improved seeds of groundnut produced in Mnanje village alone in Nanyumbu district.

The increased access of improved groundnut seed led to the increase in area and production of groundnut in the southern zone. In Nanyumbu district for example, the area and production of groundnut in the district have increased by $11 \%$ and $15 \%$, respectively. Groundnut area in the district has increased from 14,540 ha in 2012 before membership to 16,125 ha in 2018 after membership. Groundnut production in the district has increased from 12,613 ton from 2012 before membership to $14,497 \mathrm{t}$ in 2018 after membership (Fig. 2.3). The increase of area and production of groundnut in the district is attributed to the increased access to improved seed which are high yielding, resistant to pests and disease, drought resistant and with farmer and market preferred traits.

\subsubsection{Achievements in the Areas of Improved Varieties Released from 2009 to 2019}

In collaboration with partners within and outside the country, TARI Naliendele has managed to release 11 improved varieties resistant to biotic and abiotic stresses. These varieties are listed below in Table 2.3.

Out of 11 varieties released, six varieties were released during the TLIII project and the other five varieties were released during TLII project. Tropical Legume project has contributed significantly to the release of improved groundnut varieties by TARI Naliendele from 2007 to 2018. TARI Naliendele has released 11 improved varieties compared to six varieties released by the Institute since 1961 to 2006.

\subsubsection{Achievements in the Areas of Access to New Markets, Finance and Other Services}

Platform members in the southern zone have benefited from new market outlets from different parts of the country. Some of the groups in Masasi and Nanyumbu 
Table 2.3 Improved varieties released by TARI Naliendele from 2009 to 2017

\begin{tabular}{l|l|l}
\hline Variety name & ICRISAT Name & Year of release \\
\hline Naliendele 2009 & ICGV-SM 99555 & 2009 \\
\hline Mnanje 2009 & ICGV-SM 83708 & 2009 \\
\hline Mangaka 2009 & ICGV-SM 99557 & 2009 \\
\hline $\begin{array}{l}\text { Nachingwea } \\
\text { I009 }\end{array}$ & ICGV-SM 01711 & 2009 \\
\hline Masasi 2009 & ICGV-SM 01721 & 2009 \\
\hline Narinuts 2015 & ICGV SM 01731 & 2015 \\
\hline Kuchele 2015 & ICGV 8326 & 2015 \\
\hline Nachi 2015 & ICGV SM 90704 & 2015 \\
\hline Mtwaranut 2016 & ICGV-SM 07599 & 2018 \\
\hline Naliendele 2016 & ICGV-SM 08503 & 2018 \\
\hline Tanzanut 2016 & ICGV-SM 01514 & 2018
\end{tabular}

districts are contract farmers producing groundnut pre-basic seed on behalf of TARI Naliendele. These groups are provided with seeds and all the production processes are supervised by TARI Naliendele and sell the final output to TARI Naliendele at the market price plus an incentive. Other farmers in the southern zone who produces groundnut seeds have been linked to their district council which buy seeds and distribute to other villages within their district. Moreover, Non-Governmental Organization i.e. RECODA and World vision bought groundnut seeds for their farmers' networks in Singida, Tabora and Dodoma regions. Moreover, marketing of groundnut grain was done by local traders who pass door to door during harvest season to buy groundnut from famers. Other traders established temporally groundnut aggregation and collection points through cooperative societies where groundnut grain is bought from farmers. Later on, the collected groundnuts are transported to Kariakoo market in Dar es Salaam and other town market.

Traditionally, the market prices of shelled groundnut in the southern zone at farmers' level increased from TZS 1000-1200/kg during the harvest season (MayAugust) to TZS 1800-2200/kg during planting season (December-February). Nowadays, the groundnut prices have increased thanks to the market-fit varieties farmers produce. The shelled groundnut price has increased from TZS 1000-1200/ $\mathrm{kg}$ in 2014, to TZS $1500-1800 / \mathrm{kg}$ in 2018 during the harvest season. In the planting season (December-February) prices have increased from the usual TZS 1800-2200/ $\mathrm{kg}$ to TZS 2400-4000/kg. The increased price has been attributed to the use of improved varieties that fit current market demand. The improved seeds were preferred by both farmers and traders because of softness of the pod, high yielding compared to local varieties, early maturity, large-sized kernels, (confectionary type) and high oil content.

\subsubsection{Achievements in the Areas of Social Assets Including Affiliation to Associations and New Social Services}

Umoja group at Mnanje village in Nanyumbu district was the only group in the village producing groundnut before membership to SGP. But after membership, Umoja facilitated the formation of ten new groups in the nearby villages as part of platform 
activities to ensure that improved groundnut seeds are made accessible to as many farmers as possible. Income obtained from groundnut sales is used to purchase inputs (pesticides and fungicides) for cashew production in Mnanje village (the other important cash crop in the village). Shabila Musa is a female farmer (45 years old) in Masasi district. She started groundnut farming in 1999 using Pendo and Sawia released in 1998 and Johari released in 1985. Through income from groundnut farming as a member of the platform, she has been able to expand her original farm from 1 acre to 3 acres, bought another 19 acre farm, constructed two family houses and managed to take her children to school and handle the management cost for her cashew farm. Mapambano is another group in Mpeta village of Masasi district. This was the first groundnut research and production group created by TARI Naliendele and also a member of SGP. According to Andrew James, the village chairman of Mpeta, this group assisted the village with construction of two classrooms and a village dispensary using proceeds from groundnut production sales. SGP platform members have therefore gained recognition as important members of their community.

\subsubsection{Achievements in the Areas of Gender Equality and Youth}

Groundnut production in the country is cultivated by both males and females, however, women are the main providers of labour (Bucheyeki et al. 2010). The crop has been regarded as women crop because they are more involved in producing as compared to men for meeting the household food demands and income (Katundu et al. 2014). Despite, being major provider of labour for groundnut production, the major challenges faced by women in groundnut production were low yields, poor access to improved varieties, more time spent in planting and shelling groundnuts (Battista et al. 2014). To address the above-mentioned challenges, the SGP equally targeted both men and women in sensitization meetings on comparative advantages of the improved groundnut varieties. TARI Naliendele through TLIII project has procured 29 labour saving technologies, i.e. 4 ox-ploughs, 14 planters, eight threshers and three oil expellers which are being tested at different project sites including southern Tanzania. The use of these technologies will reduce drudgery in both women and men farmers in the country. Moreover, TARI Naliendele together with its partners such as NGOs, District councils and farmer groups have distributed six improved groundnut varieties that are high yielding, resistant to pests and diseases and drought tolerant. This has widened the choice and uses of varieties to farmersfor example Mangaka 2009 for high zinc (94.5 mg/kg), Mnanje 2009 for high iron $(65 \mathrm{mg} / \mathrm{kg})$ and oil $(51 \%)$ and Naliendele 2009 for high protein content $(34.5 \%$ w/w). Zinc and iron are important mineral nutrients to both men, women and children health in the society as they correct mineral malnutrition. The platform has built the capacity of both men and women in groundnut production and post-harvest technologies through business and entrepreneurship trainings, aflatoxin mitigation strategies and good agronomic practices. All these have attracted the attention of youths in the southern zone and are now producing groundnut seeds as cash crop. 


\subsubsection{Perceptions of Platform Performance}

According to platform members, the SGP has opened doors for the many social and economic opportunities as a result of improved access to the new higher yielding varieties. For them, more efforts must be done to improve market access to groundnut produced in the regions. Platform members reported that TARI Naliendele has promoted too many varieties at once in the process confusing farmers regarding which varieties to take. It was suggested by platform members to focus on at least four with key market and farmer preference attributes for specific period of time so that the few available resources for promotion are used more efficiently. The district council proposed allocation of resources for fuel to distribute and supervise groundnut production activities in their respective districts including demonstrations, seed multiplication and PVS. Moreover, some platform members particularly farmer groups proposed exchange visits with other groundnut groups doing similar activities outside their regions to share experience, enhance learning and improve efficiency in doing their business.

\subsubsection{Sustainability of Multi-Stakeholder Platforms}

The proposal the district council puts forward to allocate some resources to support groundnut production activities i.e. demonstrations, seed multiplication and PVS in their respective districts is a good indication of ownership and subsequent sustainability of the platform interventions. In addition to the local government actions, several steps have been taken by TARI Naliendele to enhance sustainability of platform activities. These include:

- Involvement of more private sector operators who have resources to facilitate seed production and marketing activities.

- To ensure that every platform member has ownership. This means they should be financed by their institutions and/or organizations to participate in the SGP meetings.

- To incorporate more stakeholders particularly traders who will buy the grain produced by farmers.

- Link groundnut producing groups with financial institution i.e. NMB Foundation for Agricultural Developments (NFAD) which has shown interest of financing these groups to support commercial groundnut production and marketing.

\subsection{Reflections on the Process}

The collaboration between Research and private sector in demand creation activities has enabled TARI Naliendele to reach more farmers throughout the country. The operating cost of facilitating the innovation process is lowered as multiple partners brought on board allocate their own resources to perform some of the activities e.g. seed production, field days and monitoring activities. Even though some platform members still think that TARI Naliendele should take a lead in financing platform activities through project fund, we believe this is not sustainable. Projects such as 
TLIII should only catalyse the bringing together of stakeholders to pursue their common interest. This is a major step forward compared to many past and recent platform experiences where everything collapses at the end of the initiating project.

\subsubsection{The Significance of Observed Achievements for the Livelihood of Different Stakeholder Involved}

The improved groundnut seed accessibility to farmers in the southern zone has led to the increased area, yield and income to all players in the groundnut value chain. Moreover, the increased private sector participation in seed industry development through seed production and distribution has changed livelihood of many farmers and groundnut stakeholders in the region by increased income and contacts to agricultural extension services. The introduction of labour-saving technologies will contribute to reduction in drudgery and save time that can be allocated to other income generating activities. Use of labour-saving technologies at scale will benefit other players in the groundnut value chain like processors and manufacturers of farm implements who will fabricate the required equipment.

\subsubsection{The Significance of Observed Achievements for the Communities at Whole}

The increased income by groundnut farmers in the southern zone have benefited villagers by building schools, dispensary and healthy centre in Mpeta and Mnanje villages in Masasi and Nanyumbu district councils. Moreover, the distribution and accessibility of high iron, zinc and protein varieties (Mangaka 2009, zinc (94.5 mg/ $\mathrm{kg}$ ), Mnanje 2009, iron (65 mg/kg), and Naliendele 2009, protein $(34.5 \% \mathrm{w} / \mathrm{w})$ ) to the farming communities have significantly contributed to the upliftment of nutritional status of pregnant women, children, and the communities at large. Significantly important, training of groundnut post-harvest technologies has helped the communities to apply aflatoxin mitigating strategies and reduce danger from aflatoxin contamination common in groundnut farming communities.

\subsection{Areas to Focus on in the Future}

Membership Fee for Running Platform Activities Platform activities and/or assignments are run by members themselves using their own resource including meetings. Membership fees could help the SGP to run administrative issues and employ some staffs to monitor the overall implementation of platform activities.

Having a Permanent Chairman and Secretariat for Specific Period of Time The chairman of the meetings and secretariats are selected by members during the meet- 
ing and can act on their position during the meeting period only. Having these posts for a certain period of time enable some important decision to be made before the annual meetings.

Establish a Platform Steering Committee The committee will monitor the implementation of the Platform's activities, resolve potential issues, and provide strategic guidance. In addition, the steering committee will assess the progress achieved by all platform members against the different action points adopted during annual meetings. The steering committee will be composed by representatives from all its member networks as agreed by members in the annual meeting.

Promoting New Improved Groundnut Varieties Released in 2018 TARI Naliendele has just released new groundnut varieties in January 2018 with good market attribute and well adapted to biotic and abiotic stresses. These varieties have not yet been exposed to farmers and other stakeholders along the groundnut value chain. Therefore, promoting these varieties now will help farmer to have alternatives in the future when replacing the old varieties that will have climate change issues.

Replicating Success of SGP Throughout the Country Key lessons learned from SGP will be replicated in lake, western, central and southern highlands zones. These lessons will enhance a well-structured groundnut market in the country and bridge information asymmetry between groundnut value chain partners.

Training on Good Agronomic Practices More farmers within and outside the SGP will be trained on good agronomic practices to increase groundnut productivity. Farmers will be able to use the recommend seed rate, appropriate spacing and other groundnut management practices.

Grain processors and/or traders creating demand for specific varieties Establish linkages between groundnut traders and/or processors with farmer groups that will have demonstrations plots to specific groundnut varieties desired by traders in different location. This will stimulate grain demand of improved groundnut and thereby creating demand for groundnut seeds produced by different partners.

\subsection{Lessons Learned}

- The wide choice of improved groundnut varieties to farmers from three old improved varieties released in 1980s and 1990s to five new improved varieties released in 2009 opens up new market opportunities for various actors. 
- The increased contact of farm advisory services using government extension officers, community extension services and lead farmers has made a big difference in reaching farmers with improved technologies and knowledge even those located in remote areas.

- The increased groundnut seed production and distribution networks by NGOs, seed companies, farmers groups and individual seed entrepreneurs have facilitated seed availability and accessibility to farmers.

- The increased area and production of groundnut in the southern zone from 14,540 ha in 2012 to 16,125 ha in 2018 and from 12,613 ton in 2012 to 14,497 ton in 2018, respectively, have proved that innovation platforms are effective and led to increased business opportunities for stakeholders along the groundnut value chain.

- The dissemination of market-fit varieties led to increased market prices of shelled groundnut in the southern zone at farmers' level from TZS $1000-1500 / \mathrm{kg}$ in 2014 to TZS $1800-4000 / \mathrm{kg}$ in 2018.

- The sustainability of platform interventions requires efforts by all players within the groundnut value chain and not the sole commitment of few development organizations.

- Working in partnership with other stakeholders creates bigger impact and reduces operating cost (monitoring and supervision costs).

\section{References}

Bucheyeki TL, Mapunda XT, Matata WL, Shenkalwa ME (2010) Groundnut client oriented research in Tabora, Tanzania. Afr J Agric Res 5(5):356-362

Battista FD, Martha O, Monika P (2014) Gender inequality in rural employment in Tanzania mainland: an overview. In: Tanzania mainland country profile. Food and Agriculture Organization of the United Nations (FAO), Rome. 64pp

Katundu M, Kumburu N, Mbeiyererwa A, Mhina M (2014) Socio-Economic Factors Limiting Smallholder Groundnut Production in Tabora Region. Research Report submitted to REPOA. $44 \mathrm{pp}$

ASARECA/KIT (2014) Tanzania Seed Sector Assessment: A Participatory National Seed Sector Assessment for the Development of an Integrated Seed Sector Development (ISSD) Programme in Tanzania. April 2014, Entebbe, Uganda. 169 pp.

Madulu RB, Gregory T, Mbapila S, Marenya P (2016) Seed value chains to support Sustainable Intensification in Tanzania. repository.cimmyt.org

Chambers A, Cortes J, Harries A (2013) SeedCLIR Tanzania, pilot report. United States Agency for International Development by the USAID enabling agricultural trade (EAT) project, Fintrac Inc. $31 \mathrm{pp}$

Kalinda T, Tembo G, Kuntashula E (2014) Adoption of improved maize seed varieties in southern Zambia. Asian J Agric Sci 6(1):33-39 
Open Access This chapter is licensed under the terms of the Creative Commons Attribution 4.0 International License (http://creativecommons.org/licenses/by/4.0/), which permits use, sharing, adaptation, distribution and reproduction in any medium or format, as long as you give appropriate credit to the original author(s) and the source, provide a link to the Creative Commons license and indicate if changes were made.

The images or other third party material in this chapter are included in the chapter's Creative Commons license, unless indicated otherwise in a credit line to the material. If material is not included in the chapter's Creative Commons license and your intended use is not permitted by statutory regulation or exceeds the permitted use, you will need to obtain permission directly from the copyright holder. 